\title{
Innovation in Uruguay: New Perspectives on Public Policies and Education
}

\author{
Ivonaldo Leite \\ Center for Applied Science and Education \\ Federal University of Paraíba, Brazil \\ Email: ivonaldo.leite [AT] gmail.com
}

\begin{abstract}
This paper aims to present a general perspective of the actions developed by the Uruguayan Broad Front, which has been defined as an example of reformed left in Latin America. The Broad Front has governed Uruguay since 2005 and has implemented several alternative and innovative policies. Methodologically, the paper is empirically supported by data and information derived of interviews conducted in Montevideo, as well of the analysis of official documents. Among the results found out, it can be highlighting the following sample: 1) innovative programmes focused on most disadvantaged young children and their families like Uruguay Crece Contigo [Uruguay grows with you] have been successfully put in place and scaled up; 2) the institution of the Salary Councils (tripartite councils made up of government representatives, businesses and workers) stimulated the formalization of work and the rise in salaries, as well as the strengthening of unions; 3) the creation of the Ministry of Social Development (MIDES) as a new centralized social authority, which shares jurisdiction with the Social Security Bank (BPS) and the Ministry of Health; 4) in the face of the failure of the so-called drug war, the regulation of the cannabis market was approved during the term of President José Mujica. Conclusively, it's affirmed, for instance, that the Broad Front perspectives and the policies it has implemented in Uruguay have instituted a new conception of the left in Latin America.
\end{abstract}

Keywords---- Uruguay, public policies, education, Broad Front, reformed left

\section{INTRODUCTION}

In 1940 Walter Benjamin wrote his Theses on the Concept of History provoked by the idea that society lived at that time in a moment of danger in countries like Germany and Italy (Benjamin, 2006). Today, it is probable that we also are living in a moment of danger, but it is a moment that is not produced only in the sphere of the State. In Benjamin's time, the danger was the rise of fascism as a political regime commanded by explicitly assumed dictators like Hitler and Mussolini. In our time, the danger is the rise of fascism as a societal regime in several countries.

In such way, we can remember the case of Galdino Jesus, an Indian Pataxó from Northeast Brazil. Some years ago, he went to Brasilia to take part in march of the landless. The night was warm, and he decided to sleep on a bench at the bus stop. In the early morning hours, he was killed by three middle-class youths. As the youngsters confessed later on to the police, they killed the Indian for the fun of it.

Societal fascism can be defined as a set of social processes by which large bodies of populations are irreversibly kept out or thrown out of any kind of social contract (Santos, 2001). So, they are rejected, excluded and thrown into a kind of Hobbesian state of nature, either because they have never been part of any social contract and probably never will; or because they have been excluded or thrown out of whatever social contract they had been part of before.

In Europe, United States and Latin America, far-right populist political positions have defended ideas identified with the societal fascism. For example, racist ideas. On the other hand, neoliberal agendas around the world generate social exclusion. Far-right populists and neo-liberals are two sides of the same coin. The coin of conservative modernization. Both attack workers' right and institutions as the public school.

In addition to the far-right populists and neo-liberals, the alliance that supports the conservative modernization is still constituted by two other groups: neo-conservatives and a particular fraction of the upwardly mobile middle class. However, neoliberalism is the most powerful ideological element within conservative modernization. As a rule, according to neoliberals, what is private is necessarily good and what is public is necessarily bad. Therefore, public institutions such as schools are presented by the neoliberalism as 'black holes' into which money is poured - and then seemingly disappears -, but which do not provide anywhere near adequate results (Apple, 2001).

The conservative modernization, under leadership of the far-right populists and neo-liberals, has won the battle over common sense. They have skillfully stitched together different perspectives and commitments and have organized them under its own headship in matters dealing with social welfare, culture, economy and education. Probably, Brazilian government is today the most evident example of the alliance between far-right populists and neo-liberals.

By conservative modernization, the economic rationality is more powerful than any other. In the educational field, such a position conceives the students only as human capital. It means that the world is extremely competitive economically, and the students as future workers must receive the requisite skills and dispositions to compete efficiently and effectively. Other crucial idea here is consumer (Apple, 2001). This is, the world is a big supermarket, and "consumer 
choice" is the guarantor of democracy. Consequently, education is seen as merely one more product like rice, cake and cell phone. In this way, in last instance, democracy is turned into consumption practices. The ideological effects of such point of view are momentous. Rather than democracy being a political concept, it is transformed into an entirely economic concept (ibidem).

However, in this work, I'll develop an approach that is in opposite side to the conservative modernization. I'll focus the case of the Uruguayan reformed left governments and their perspectives about public policies, which can be defined as counterhegemonic perspectives, as we will see it. Methodologically, the work is the result of a postdoctoral research carried out in Montevideo, Uruguay. Empirically, it is supported by data and information derived from interviews and documentary analysis.

\section{THE URUGUAYAN REFORMED LEFT}

The left political is a concept that encompasses a wide variety of political currents, from communism to socialism, and from social democracy to progressive liberalism. In Uruguay, such reality is very perceptible. The Broad Front (Frente Amplio, in Spanish), as a left coalition party, brings together communists, socialists, popular-nationalists, social democrats and left Christians. The Broad Front was founded in 1971, and it was declared illegal during the 1973 military coup d'état. It arisen again in 1985 when democracy was restored in Uruguay.

Except during the period of military rule, Uruguay had been governed since independence, in 1828, until 2004 by two parties - the Colorado and National Party. Historically, both are heterogeneous political forces, with the Colorado Party affiliated with urban groups and the National Party representing rural areas (Hudson \& Meditz, 1992). However, in 2004, the Broad Front won the presidential and congressional elections. Tabaré Vázquez, a doctor specialized in oncology, was elected President of the Republic and ended 170 years of political domination of the traditional parties.

President Vázquez was inaugurated to a five-year term in March 2005, and Uruguay was just beginning to recover from the 2001-03 crisis, which was mainly caused by the spillover effects of the economic problems of Argentina and Brazil ${ }^{1}$. He adopted a political perspective that has been defined as reformed left (Swagerman, 2014). Such perspective seems to conceive the left as a "current of thought, politics, and policy that stresses social improvements over macroeconomic orthodoxy, egalitarian distribution of wealth over its creation, sovereignty over international cooperation, democracy (at least when in opposition, if not necessarily once in power) over governmental effectiveness" (Castañeda, 2006, p. 32).

Therefore, President Vázquez opened the door to a new, bold political direction. He worked at stabilizing the economy, signed a three year $\$ 1.1$ billion stand-by arrangement with the IMF that committed Uruguay to a substantial primary fiscal surplus, low inflation and a reduction in foreign debt. On the other hand, this agreement, combined with a mix of pro-investment policies and social programs, contributed to revitalize the Uruguayan economy in a short period of time. "His \$240 million National Plan to Address Social Emergency contributed to reduce poverty. He established wage councils made up of representatives from unions, business and government to negotiate wages for 100,000 firms and 600,000 workers. Hundreds of jobs were created under the Work for Uruguay Program, pushing unemployment down from 12.3 per cent to 7.3 per cent, its lowest level in decades" (Yoldi, 2010, p. 6). In addition to it, he reduced value added tax on basic food items, and created a personal income tax that exempts the poorest 60 per cent. President Vázquez also made efforts to decentralize government and encourage greater popular participation in politics.

The Vázquez Administration's labor reforms increased considerably the of unions, playing a substantial role in the percentage of unionized workers more than doubling between 2005 and 2007 to approximately $24 \%$ of the labor force. President Vázquez and the Broad Front also overhauled the tax system to make it more progressive, reducing the valueadded tax and replacing the tax on wages with a personal income tax that exempted the poorest $60 \%$.

The Vázquez Administration was widely approved by the population, and this fact contributed to a second victory of the Broad Front in the 2009 elections. But the candidate had his own merits. It was José Mujica, and his suffering at the hands of the military gave him great credibility among voters, since he is a man who paid a high price for his ideas. Mujica was imprisoned for 14 years as a result of his activities as one of the leaders of the Tupamaro National Liberation Movement, a leftist urban guerilla group that operated in Uruguay during the 1960s and 1970s. Following the return to democracy, Mujica helped to create the Popular Participation Movement (MPP), which is the largest group within the Broad Front coalition. He was elected to Uruguay's lower house in 1994 and to the Senate in 1999, before serving as minister of livestock, agriculture, and fisheries during the Vázquez Administration. José Mujica was inaugurated to a fiveyear term in 2010 .

Although the former guerrilla is politically different from his predecessor, he is also a consensus-builder, such as Vázquez. Moreover, Mujica has made it clear that there is no contradiction between embracing revolutionary ideals and seeking conciliation, as well as assuming more moderate positions. He and Vázquez are the most representative faces of the reformed Uruguayan left.

President Mujica became known for his modest lifestyle, as well as for his reflections on the human being and contemporary world. Hence, he also became known as the philosopher president. During his administration, he donated 90 per cent of his salary to charities for the poor and entrepreneurial start-ups, preferring to live on the farm owned by his wife just outside Montevideo rather than the president's official residence, and eschewing state limousines for his battered Volkswagen Beetle. He has not taken to the trappings of power. 
He continued the actions of his predecessor and developed bold policies that, for example, reduced the number of Uruguayans living below the poverty line and were responsible for a new approach to drugs, which regulated the cannabis market. So, Mujica concluded his term as a President popular, with a 65 percent approval rating. As a leader of the Uruguayan reformed left and as consequence of the public polices of his administration, he was described as the mentor of a calm revolution (Rabuffetti, 2014).

In Uruguay, consecutive reelection is not allowed. Thus, in the 2014 elections, the Broad Front presented as candidate the former President Tabaré Vázquez. The success of the Broad Front's public policies, Mujica's calm revolution, and Vazquez's popularity ensured his victory in the second round. He defeated Luis Lacalle Pou, a leader of the conservative National Party. Therefore, the Uruguayan reformed left won its third consecutive term.

President Vázquez was inaugurated to a five-year term in 2015. Overall, he has maintained the Broad Front's public policy guidelines. One of the facts that have marked his second administration is the victory in the so-called Philip Morris case. This is, in 2010, the multinational tobacco company Philip Morris filed a complaint against Uruguay, claiming that the Uruguayan smoking legislation devalued its cigarette and trademarks and investments in that country, and so demanded for compensation under the bilateral investment treaty between Switzerland and Uruguay. A fight between the world's largest cigarette manufacturer and a small South American country; a 'true David and Goliath story'. Such treaty provides that disputes are settled by binding arbitration before the International Centre for Settlement of Investment Disputes (ICSID).

On 8 July 2016, the ICSID ruled in favor of Uruguay, and Philip Morris not only lost the case but was ordered by the court to pay South American country about $\$ 7$ million in legal fees. It has been seen as a Vázquez's political victory and as an important moment for public health in the fight against the deregulation of the activities of the tobacco industry.

However, on the other hand, in last times, the conservative opposite has intensified its criticisms and actions against the Vázquez administration and the Broad Front. Sometimes it proceeds like some Brazilian groups that deposed the former president Dilma Rousseff and made feasible the arrival of Jair Bolsonoro to the Presidency of the Republic. This is the case, for instance, of some segments of the so-call One Movement Only Uruguay. Such movement presents itself as an organization that aims to raise awareness to avoid 'complex situations' that were experienced in recent history and affirms that it feels the need to warn before it is to late (Un Solo Uruguay, 2018). This is the same far right-wing and populist rhetoric used in Brazil.

President Tabaré Vázquez's term is nearing its end, and in 2019 there will be a new election. Such rhetoric is a demonstration of the kind of dispute that is likely to occur during the election campaign.

\section{PUBLIC POLICIES AND EDUCATION UNDER THE URUGUAYAN REFORMED LEFT} ADMINISTRATIONS

The Uruguayan reformed left administrations are a case of social democracy in contrast to other contemporary left experiences (Lanzaro, 2011). Such administrations are formed by an institutional left and conducted by left parties with a solid trajectory, within the framework of a plural and competitive party system. However, to a large degree Broad Front continues to hold ideologically left positions. In its bids for the Presidential elections, it launches a two-pronged strategy (ibidem): it incorporates the programmatic changes demanded by competition, but it keeps up an unyielding opposition towards the parties of the establishment and the neoliberal prospects. So, the ideological moderation, typical of any catchall party, is in this case limited, passing through an incessant intraparty dispute, with sectors that exhibit different degrees of assimilation or resistance to the liberal perspectives.

The Broad Front administrations have developed a significant number of innovative public policies, for instance, in the area of human rights and with respect to economic and social context, cultivating a moderate reformism, but, at the same time, it is an audacious reformism that composed a counter-hegemonic social democratic agenda.

The public policies carried out by the Broad Front administrations are an outcome of the political framework that it has been emphasized above. I will present from now on a sample of them, constituted of the educational policy, social policy, labor policy and human rights policy. I will put more emphasis on education, because there are dimensions about it that must be taken into account more largely. So, I am going to start by such topic.

First of all, it is important to underline how the 'philosopher president' conceives the education, because José Mujica has presented reflections in this sense, and thus he has exercised some influence in the development of educational actions. At least during the period in which he was President ${ }^{2}$. Some of his ideas about education are as follows (Mujica, 2009; Martin McQuillan, 2015):

1. As we are going, knowledge repositories are not going to be inside our heads anymore, but outside of us, available to be searched for in the internet. It will be there all the information, all the data, everything that is already known. In short, it will be there all answers. What will not be are all the questions. The ability to ask questions is what will be important. The ability to ask deep questions that trigger new research and learning efforts.

2. "The intelligence that contributes most to a country is the distributed intelligence. It is the one that is not only kept in the laboratories or in the universities, but the one that walks through the streets. The intelligence that is used to plant, to program a computer or to cook, it is the same intelligence. Some have climbed more steps than others, but it's the same ladder. The steps below are the same for both nuclear physics and field management. It's necessary a curious and nonconformist look, as well as an active position interested in new knowledge" (ibidem, p. 2). 
3. "I have a dream in which parents show the grass to their children and ask them: do you know what is this? And they answer: it is an energy processing plant of the sun and minerals of the earth. Or yet that parents show to their children the starry sky, and make them think about the celestial bodies, the speed of light and the transmission of waves" (Mujica, 2009, p. 3).

4. Education has the transformative power to contribute to greater justice and less inequality in society. However, educational policy is not neutral, and so it needs to be guided towards a purpose by a political agenda.

5. Education, and especially the university, can be an instrument of division that serves the interests of elites, preserving or increasing inequality. Therefore, education cannot be separated from democracy, as a tool that must assist the most people to improve their condition in life.

6. Universities must create another culture; a universal humanistic culture, above nations, that must create common values for the human beings.

7. The universities are the place where we charge our batteries to create new ideas in society.

8. In the modern world the abandonment of philosophy is the main cause for the loss of values beyond market economics.

9. The modern world gives us so much to see, but we do not really see it without philosophy.

10. Philosophy is not just something to be learned in a university, but it must be a permanent questioning.

11. We can get to the point where studying, researching and learning is no longer an effort, it is pure pleasure.

12. Humankind possesses the knowledge and technological innovation to solve its problems, but what is missing is a political mentality to do it.

Overall, Broad Front administrations have been in agreement with the Mujica's approach to education. So, as the Economic Commission for Latin America and the Caribbean (ECLAC, CEPAL in Spanish) recognizes, education has also been one of the priorities of its governments (CEPAL, 2009). This is reflected in the significant increase that has occurred in public spending, which went up as a proportion of overall social spending and as a percentage of GDP. Public spending on education is projected to reach $6 \%$ of GDP in 2020.

There have been important measures aimed at the development of science and technology, as the creation of the National Agency of Research and the consolidation of the National System of Researchers. Moreover, other important measures are, for instance, as follows: the program of "community teachers", supporting primary school students in vulnerable areas; the Program for the Universalization of Secondary Education, which seeks to overcome alarming education failures at the secondary level; and the Ceibal Plan (named after the Uruguay's national flower), inspired by the international One Laptop per Child initiative, which seeks to generalize an early introduction to computing. "Uruguay has been a pioneer in carrying out this democratizing initiative on a national scale, which was imposed widely and with great connectivity" (Lanzaro, 2011, p. 33).

In a 2015 report, UNICEF highlighted the progress of the Uruguayan educational policies. It affirmed that in the last times an important progress was made regarding development and strengthening of public policies devoted to early childhood and to education in Uruguay. According to UNICEF (2015), innovative programmes focused on most disadvantaged young children and their families like Uruguay Crece Contigo have been successfully put in place and scaled up. At the same time, UNICEF emphasized (ibidem, p. 7) that the "school programmes aimed at improving learning achievements like 'Maestros Comunitarios' and the programme 'Aprender' were carried out in many schools throughout the country reaching an increasing number of children. At secondary schools, programmes developed to reduce dropout rates have provided a very valuable new approach to this issue."

Public policies for labor relations maybe is one of the spheres where the historical identity of the Broad Front has been reaffirmed more significantly, as I have previously emphasized. The Uruguayan left has historically maintained a close relationship with labor unions. "This kinship was a decisive factor in the 1960s political events, which led firstly to the unification of the national labor federation (1964) and afterward to the foundation of the Frente Amplio [Broad Front] (1971). In a typical social democratic path, a fundamental connection was forged between the unions and the left party, though each part also managed to maintain significant and shifting margins of autonomy" (Lanzaro, 2011, p. 34). Such relationship has strongly reflected in the Broad Front administrations. For instance, in the first term of Tabaré Vázquez, almost thirty members of the initial team were of union extraction.

Therefore, the policy adopted by the Vázquez administration with respect to labor relations had the clear stamp of the left and reinforced the relationship between the Broad Front and the unions. Perhaps, the most noteworthy measure in this area was the reinstatement of the Salary Councils ${ }^{3}$. According to what I have already pointed out in this paper, these are tripartite councils made up of government representatives, businesses and workers, which institutionalize collective negotiations by branch of activity, in order to determine salaries and regulate labor relations.

The institution of the Salary Councils stimulated the formalization of work. They include, in addition to the traditional workforce, public employees, rural laborers and domestic workers. The good results of the economy and the actions taken by the government have increased the value of the salaries. The Broad Front administrations sought to reverse the fall in real private salaries, which amounted to a reduction of $25 \%$ between 1998 and 2004. However, under the governments of the Uruguayan reformed left, salaries have been recovering year after year. For example, by the end of the period 2005-2010, they reached almost five points above the 1998 level, as it can seen in the below figure. 
Figure 1 - Real Wage Evaluation (1998-2010)

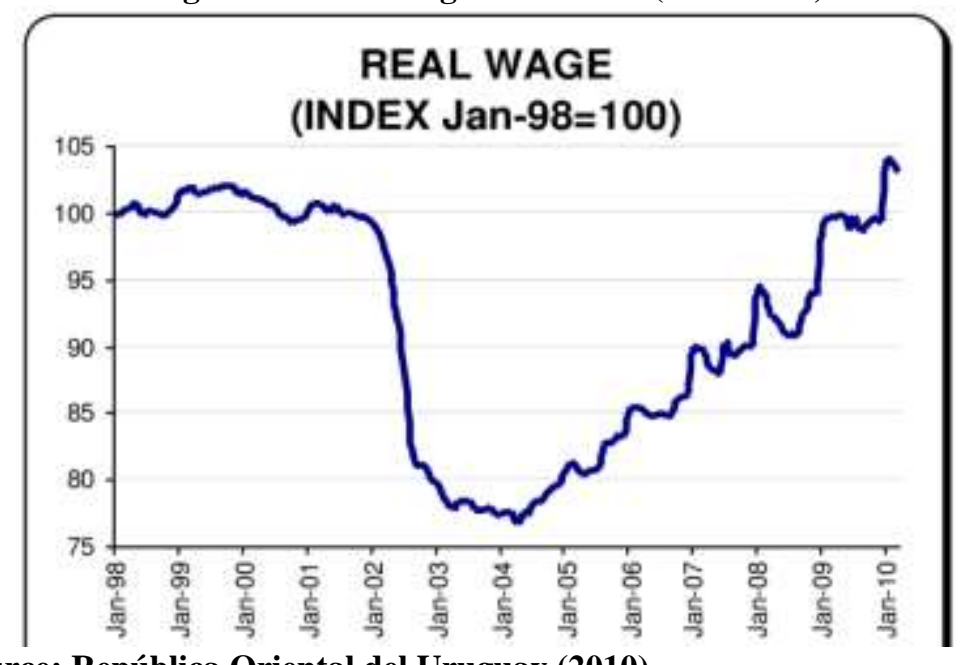

Source: República Oriental del Uruguay (2010)

In the context of social policy, the governments of the Uruguayan reformed left have developed several actions that reinforce the presence of the political dimension in the approach to social welfare, as well as reinforce the intervention of the State in this context. Some of such actions are as follows:

1. Development of a strategy that combines universal benefits and policies targeted at the most vulnerable sectors (children, young people and female heads of household). This included the launch of conditional transfer programs (CTPs).

2. The creation of the Ministry of Social Development (MIDES) as a new centralized social authority, which shares jurisdiction with the Social Security Bank (BPS) and the Ministry of Health.

3. The Equity Plan, a permanent program of social protection, which prioritizes young people and their parents, but it also covers other vulnerable groups, such as the elderly. It centers on cash transfers, making new contributions to old-age pensions and especially to family allowances.

4. The "Work for Uruguay" program, which offers temporary employment and training courses, attempting to construct routes out of poverty.

5. Institutionalization of the social policy programs such as State programs, allowing social provisions to reach beneficiaries on the basis of rights and via bureaucratic channels rather than through clientelistic linkages.

The priority given to social policy is reflected in the increase in social spending. According to the Economic Commission for Latin America and the Caribbean, between 2004 and 2008, overall public spending increased each year by $30 \%$ in absolute terms, and public social spending per capita, in turn, went up, both in absolute and relative terms, having an accumulated increase of $41 \%$ in real terms during this period, putting public social spending above the average percentage of GDP spent in Latin America (CEPAL, 2009).

In the area of human rights, the policies of the Broad Front administrations have achieved a great projection. Such policies have positioned Uruguay on the leading edge of lesbian, gay, bisexual, and transgender (LGBT) rights in Latin America by allowing LGBT individuals to serve openly in the military, legalizing adoption by same-sex couples, allowing individuals to change official documents to reflect their gender identities, and legalizing same-sex marriage. Moreover, the Uruguayan reformed left, has approved the decriminalization of abortion and the regulation of the Cannabis market, from production to consumption.

The regulation of the cannabis market is one of the boldest policies of the Broad Front administrations. It was a decision of President José Mujica taking into account two aims: on the one hand, to reduce the potential risks and harmful effects of smoking marijuana for recreational purposes, and on the other hand to take the cannabis market out of the hands of criminal networks and to separate the licit cannabis market from the illicit market of more harmful substances. The Uruguayan regulation instituted three ways of access to cannabis: homegrow, commercial purchase and cannabis clubs. The Law 19.172 established, for instance, the following rules for regulation:

1. Cultivation of hemp for industrial purposes (containing less than 1 per cent THC) falls under the responsibility of the Ministry of Livestock, Agriculture and Fisheries.

2. Cultivation of psychoactive cannabis (containing more than 1 per cent THC) for medical purposes, scientific research or "for other purposes" requires prior authorization from the Institute for the Regulation and Control of Cannabis (IRCCA). 3. Cultivation of cannabis for personal consumption or shared use at home is permitted up to six plants with a maximum harvest of 480 grams per year.

4. Membership clubs with a minimum of 15 and a maximum of 45 members, operating under control of the IRCCA, are allowed to cultivate up to 99 cannabis plants with an annual harvest proportional to the number of members and conforming to the established quantity for non-medical use. 
5. IRCCA licenses pharmacies to sell psychoactive cannabis for therapeutic purposes on the basis of medical prescription, and for non-medical use up to a maximum of 40 grams per registered adult per month.

6. Any plantation operating without prior authorization shall be destroyed upon the order of a judge.

\section{CONCLUSION}

In conclusion, I return to the initial point. The Broad Front perspectives and the policies it has implemented in Uruguay have instituted a new conception of the left in Latin America. It's a reformed left. Its public policies focus on institutional social democratic capacity-building with counter-hegemonic approaches and initiatives. In this way, both regulation of the cannabis market and the valorization of the State's role in the economic activity and social policies are two central evidences.

The political success of the Broad Front can possibly be explained, according to what Lanzaro (2011) states, as a result of three factors: i) its development as a catch-all and electoral party, maintaining nevertheless a relative robust organization as well as its kinship with trade unions and social movements; ii) its structure as a coalition-party, unifying all left groups and having at the same time a wide electoral dragnet; and iii) its two-pronged strategy, combining opposition against neoliberal reforms and privatizations, in defense of the statist tradition, with trends towards ideological moderation.

The large ideological spectrum of the Broad Front (including socialists, communists, popular-nationalists, ex Tupamaro guerrillas converted to electoral politics, Christian left, and even sectors split from the traditional parties) constitutes a structure that casts a wide electoral dragnet, making it a strong and competitive political force. On the other hand, the Uruguayan reformed left administration is a case of majority presidentialism, which includes strong presidential leadership and operates at the same time as a sort of cabinet government due to the FA's nature as a coalition-party.

In short, the transformations of the Broad Front governments involve, for example, advances in human rights and education, tax reform in favor of a progressive income, reinstatement of the salary councils, social policies that target cash transfers, universal family allowances and improvements in health, as well as labor policies that favor the working class.

2019 will be a decisive year for the Broad Front. There will be a new presidential election in October and the coalition-party will try to win another term. It will face a large conservative and right-wing alliance that intends to repeal policies implemented by the Vázquez and Mujica administrations. But anyway, the tree of the reformed left has already flourished in Latin America.

\section{REFERENCES}

- Apple, M. (2001): Educating the "right" way, New York: Routledge Falmer.

- Benjamin, W. (2006): Selected writings: volume 4, 1938-1940, edited by Howard Eiland and Michael W. Jennings. Cambridge: Harvard University Press, 2006.

- Castañeda, J. G. (2006): 'Latin America's left turn', in Foreign Affairs, 85(3), p. 28-43.

- CEPAL (2009): Panorama social de América Latina, Santiago do Chile: Naciones Unidas/CEPAL.

- Hudson, R. A.; Meditz, S. W. (1992): Uruguay: a country study, 2nd, Washington, DC: Federal Research Division, Library of Congress.

- Lanzaro, J. (2011): Uruguay: A government social democratic in Latin America, in Steven Levitsky \& Kenneth Roberts (eds.), The resurgence of the Latin American left, Baltimore: The Johns Hopkins University Press.

- Meyer, P. J. (2010): Uruguay: Political and Economic Conditions and U.S. Relations, in Congressional Research Service, Washington, DC.

- Mujica, J. (2009): Discurso de José Mujica a los intelectuales. Montevideo: Frente Amplio.

- Rabuffetti, M. (2014): José Mujica - La revolución tranquila, Montevideo: Aguilar.

- República Oriental del Uruguay (2010): Uruguay en cifras 2010, Montevideo: INE.

- Santos, B. de. S. (2001): Nuestra America: Reinventing a subaltern paradigm of recognition and redistribution, in Theory, Culture and Society, London, Vol. 18(2-3), p. 185-217.

- Un Solo Uruguay (2018): Definición de la identidad de un Solo Uruguay, http://unsolouruguay.uy/definicion-dela-identidad-de-un-solo-uruguayl (accessed November 6, 2018).

- UNICEF (2015): Annual report 2015 - Uruguay, New York: UNICEF.

- Yoldi, O. (2010): Uruguay: the quest for just society, in Refugee Transitions, Fairfield, 24, p. 2-7. 


\footnotetext{
${ }^{1}$ Although Uruguay has long been one of Latin America's most stable economies, it experienced a major economic and financial crisis between 1999 and 2002, which was principally the result of the spillover effects of the economic problems of its much larger neighbors, Argentina and Brazil. During the crisis Uruguay's economy contracted by $11 \%$, unemployment climbed to $21 \%$, and over one-third of the country's 3.5 million citizens found themselves living below the poverty line (Meyer, 2010).

${ }^{2}$ On the other hand, it should be taken into account that the planning and management of the Uruguayan educational system are basically carried out by the National Administration of Public Education (ANEP), which is an autonomous state institution.

${ }^{3}$ In Uruguay, the Salary Councils were instituted by law for the first time in 1943. The aim was to deepen the inwardoriented model of development of the time, creating a "new world" of relations between capital and labor. The system was terminated in 1968. The situation subsequently worsened after the dictatorship that was installed in 1973 repressed unions.
} 